\title{
Diversity and Antimicrobial Activities of Actinobacteria Isolated from Tropical Mangrove Sediments in Malaysia
}

\author{
Learn-Han Lee, ${ }^{1}$ Nurullhudda Zainal, ${ }^{1,2}$ Adzzie-Shazleen Azman, ${ }^{1}$ Shu-Kee Eng, ${ }^{1,3}$ \\ Bey-Hing Goh, ${ }^{1}$ Wai-Fong Yin, ${ }^{2}$ Nurul-Syakima Ab Mutalib, ${ }^{4}$ and Kok-Gan Chan ${ }^{2}$ \\ ${ }^{1}$ Jeffrey Cheah School of Medicine and Health Sciences, Monash University Malaysia, 46150 Bandar Sunway, \\ Selangor Darul Ehsan, Malaysia \\ ${ }^{2}$ Division of Genetics and Molecular Biology, Institute of Biological Sciences, Faculty of Science, University of Malaya, \\ 50603 Kuala Lumpur, Malaysia \\ ${ }^{3}$ School of Science, Monash University Malaysia, 46150 Bandar Sunway, Selangor Darul Ehsan, Malaysia \\ ${ }^{4}$ UKM Medical Molecular Biology Institute (UMBI), UKM Medical Centre, Bandar Tun Razak, 56000 Cheras, \\ Kuala Lumpur, Malaysia
}

Correspondence should be addressed to Learn-Han Lee; lee.learn.han@monash.edu

Received 3 June 2014; Accepted 16 July 2014; Published 5 August 2014

Academic Editor: Raúl Rivas

Copyright (C) 2014 Learn-Han Lee et al. This is an open access article distributed under the Creative Commons Attribution License, which permits unrestricted use, distribution, and reproduction in any medium, provided the original work is properly cited.

\begin{abstract}
The aim of this study was to isolate and identify Actinobacteria from Malaysia mangrove forest and screen them for production of antimicrobial secondary metabolites. Eighty-seven isolates were isolated from soil samples collected at 4 different sites. This is the first report to describe the isolation of Streptomyces, Mycobacterium, Leifsonia, Microbacterium, Sinomonas, Nocardia, Terrabacter, Streptacidiphilus, Micromonospora, Gordonia, and Nocardioides from mangrove in east coast of Malaysia. Of 87 isolates, at least 5 isolates are considered as putative novel taxa. Nine Streptomyces sp. isolates were producing potent antimicrobial secondary metabolites, indicating that Streptomyces isolates are providing high quality metabolites for drug discovery purposes. The discovery of a novel species, Streptomyces pluripotens sp. nov. MUSC $135^{\mathrm{T}}$ that produced potent secondary metabolites inhibiting the growth of MRSA, had provided promising metabolites for drug discovery research. The biosynthetic potential of 87 isolates was investigated by the detection of polyketide synthetase (PKS) and nonribosomal polyketide synthetase (NRPS) genes, the hallmarks of secondary metabolites production. Results showed that many isolates were positive for PKS-I (19.5\%), PKS-II (42.5\%), and NRPS (5.7\%) genes, indicating that mangrove Actinobacteria have significant biosynthetic potential. Our results highlighted that mangrove environment represented a rich reservoir for isolation of Actinobacteria, which are potential sources for discovery of antimicrobial secondary metabolites.
\end{abstract}

\section{Introduction}

Actinobacteria represent a significant component of the microbial population in most soils including the mangrove region [1]. This phylum of bacteria has been extremely useful to the pharmaceutical industry due to their seemingly unlimited capacity to produce secondary metabolites with diverse biological activities and chemical structures [1-4]. Approximately $50 \%$ of Actinobacteria are from the genus Streptomyces, and approximately $75 \%$ of commercially useful antibiotics are derived from this genus [5].
In recent years, the chances of discovering novel biologically active molecules from various known soil bacteria (including Actinobacteria) have reduced, implying that a saturation effect could be occurring. The isolation of known Actinobacteria such as Streptomyces from various environments was found to be producing similar compounds [6]. Furthermore, the emergence of multidrug resistant pathogenic bacteria such as MRSA and fungus has resulted in critical demand for new natural products and chemical compounds in pharmacology, which in turn has made the exploration of poorly exploited areas such as the mangrove 
environments essential to discover novel Actinobacteria and novel metabolites $[1,7,8]$.

The mangrove forests are highly productive ecosystems that provide vital protections to the coastline located in the tidal zones in the tropical and subtropical areas. These ecosystems are habitat to diverse flora and fauna of marine, freshwater, and terrestrial species [9]. In contrast to the welldocumented species diversity of larger animals and plants in these mangrove ecosystems, the diversity of microbial community in the mangrove environments needs to be improved $[1,10,11]$.

The constant changes in the environmental factors such as tidal gradient and salinity in the mangrove environments are understood to be the driving force for metabolic pathway adaptations that could lead to the production of unusual metabolites. Therefore, there had been increasing exploitation of the mangrove microorganism resources [1, 12]. Many researchers discovered that the poorly explored mangrove environments contain high populations of novel Actinobacteria, as demonstrated by the isolation of Asanoa iriomotensis [13], Nonomuraea maheshkhaliensis [14], and Streptomyces xiamenensis [10]. Furthermore, many strains are also prolific producers of useful antibiotics [1, 11, 15]. Many Actinobacteria isolates from marine environments contain polyketide synthetase (PKS) and nonribosomal polyketide synthetase (NRPS) pathways, the characteristics of secondary metabolites production [16].

The Tanjung Lumpur mangrove forest located on the east coast of Peninsular Malaysia is mostly unexplored; therefore, this location is anticipated to be able to provide a rich source of Actinobacteria, the prolific producers of antimicrobial secondary metabolites. To our knowledge, no studies have reported the diversity and antimicrobial activities of Actinobacteria from Tanjung Lumpur mangrove environment. Therefore, there is a high possibility to identify novel Actinobacteria and discover valuable antimicrobial secondary metabolites. The aim of this study was to isolate and identify the Actinobacteria and screen them to discover potential sources for antimicrobial secondary metabolites.

\section{Materials and Methods}

2.1. Environmental Sampling. Soil sediments were collected from Tanjung Lumpur mangrove forest located in the city of Kuantan, State of Pahang, in December of the year 2012. Four different mangrove sediments were collected at site MUSC-TLS1 $\left(3^{\circ} 48^{\prime} 3.2^{\prime \prime} \mathrm{N} 103^{\circ} 20^{\prime} 11.0^{\prime \prime} \mathrm{E}\right)$ until MUSC-TLS4 $\left(3^{\circ} 48^{\prime} 21.3^{\prime \prime} \mathrm{N} 103^{\circ} 20^{\prime} 3.3^{\prime \prime} \mathrm{E}\right)$. At each site, five-sediment core samples were collected at a depth of $0-30 \mathrm{~cm}$ within a $50 \mathrm{~m}^{2}$ area. The sediments from each site were bulked and homogenized to prepare the composite samples. Sediments were placed into sterile plastic bags using an aseptic metal trowel and kept in the dark for transport to the laboratory. The physicochemical parameters such as temperature and $\mathrm{pH}$ of the sampling area were determined using soil temperature profile sensor ST01 and ph meter. There was little fluctuation in temperature and $\mathrm{pH}$ of the sampling locations. The temperature of soil samples ranged between 23 and $25^{\circ} \mathrm{C}$ and slightly acidic pH were observed in all the samples (6.1-6.4).

2.2. Selective Isolation of Actinobacteria. Air-dried soil sediment ( $\sim$ days) was ground with mortar and pestle. Selective pretreatment of the samples was performed using a phenol solution $\left(1.5 \%, 30 \mathrm{~min}\right.$ at $\left.30^{\circ} \mathrm{C}\right)$ [17] or wet heat in sterilized water $\left(15 \mathrm{~min}\right.$ at $\left.50^{\circ} \mathrm{C}\right)$ [18]. The pretreated samples were diluted $1: 10 \mathrm{v} / \mathrm{v}$ with sterile $25 \%$ Ringer's solution and serial dilution to $10^{-4}$. One hundred $\mu \mathrm{L}$ of the $10^{-1}, 10^{-2}, 10^{-3}$, and $10^{-4}$ suspensions was spread in triplicate onto isolation media.

Dilutions of soil suspensions were spread onto 6 different types of isolation media: ISP 2 (yeast malt agar), ISP 7 (tyrosine agar) [19], starch casein agar (SCA) [20], Streptomyces agar (SA) [21], Actinomycetes isolation agar (AIA) [21], and nutrient agar [22]. All media were supplemented with cycloheximide $(50 \mathrm{mg} / \mathrm{L})$, nystatin $(50 \mathrm{mg} / \mathrm{L})$, and nalidixic acid $(20 \mathrm{mg} / \mathrm{L})$ [23] and incubated at $28^{\circ} \mathrm{C}$ for $1-4$ weeks. Purified cultures were maintained on ISP medium 2 [19] slants at room temperature for short-term storage and as glycerol suspensions $(20 \%, \mathrm{v} / \mathrm{v})$ at $-80^{\circ} \mathrm{C}$ for long-term storage.

2.3. Morphological, Physiological, and Biochemical Characterizations of 87 Isolates of Actinobacteria. The cultural, morphological, biochemical, and physiological characterizations of the Actinobacteria isolates were performed as described by Shirling and Gottlieb [19]. Light microscopy (80i, Nikon) and scanning electron microscopy (JEOL-JSM 6400) were used to observe the morphologies of selected isolates after incubation on ISP 2 medium at $28^{\circ} \mathrm{C}$ for 7 days. Using the light microscope, the formation of aerial and substrate mycelium and spore arrangement was observed. Cultural characteristics of isolates, which include growth, colony color on different isolation media, the presence of aerial and substrate mycelium, distinctive reverse colony color, and diffusible pigment, were determined using six different isolation media including ISP 2, ISP 7, SCA, SA, AIA, and nutrient agar with procedures as described by International Streptomyces Project (ISP). The production of melanoid pigments was examined using tyrosine agar (ISP 7). The ISCC-NBS colour charts were used to determine the names and designations of the colony colours [24].

Biochemical characterizations such as Gram staining and blood hemolysis were performed. Gram staining was performed by standard Gram reaction and was confirmed by using $\mathrm{KOH}$ lysis [25]. Hemolytic activity was performed in blood agar medium containing $5 \%(\mathrm{w} / \mathrm{v})$ peptone, $3 \%(\mathrm{w} / \mathrm{v})$ yeast extract, $5 \%(\mathrm{w} / \mathrm{v}) \mathrm{NaCl}$, and $5 \%(\mathrm{v} / \mathrm{v})$ human blood [26]. Plates were examined for hemolysis after incubation at $32^{\circ} \mathrm{C}$ for 5 days. The presence of clear zone around colonies signifies the potential of isolates for surfactant production. Physiological characterization such as growth temperature was performed. The growth temperature was tested at $12-52^{\circ} \mathrm{C}$ at intervals of $4^{\circ} \mathrm{C}$ on ISP 2. The Biolog GenIII MicroPlates were used according to manufacturer's instructions to determine a 
total of 71 carbon-source utilization assays and 23 chemical sensitivity assays for selected isolates.

2.4. Preliminary Screening of Actinobacteria Isolates for Antimicrobial Activity. Eighty-seven isolates were preceded to preliminary screening for antimicrobial activity by using the cross streak method [27]. The isolates were cross streaked on ISP 2 medium and incubated at room temperature for 5-7 days. After observing a good growth of Actinobacterial cultures, overnight cultures of 12 different pathogens were used for the screening; namely, Bacillus subtilis ATCC $31098^{\mathrm{T}}$, Bacillus cereus NBRC $13494^{\mathrm{T}}$, Enterococcus faecalis NBRC $12965^{\mathrm{T}}$, methicillin-resistant Staphylococcus aureus (MRSA) ATCC BAA-44 ${ }^{\mathrm{T}}$, Staphylococcus epidermidis ATCC $12228^{\mathrm{T}}$, Aeromonas hydrophila ATCC $7966^{\mathrm{T}}$, Acinetobacter calcoaceticus NBRC $13006^{\mathrm{T}}$, Klebsiella oxytoca NBRC $12582^{\mathrm{T}}$, Klebsiella pneumonia NBRC $14440^{\mathrm{T}}$, Pseudomonas aeruginosa NRBC $12582^{\mathrm{T}}$, Salmonella typhi ATCC $19430^{\mathrm{T}}$, and Yersinia pseudotuberculosis NBRC $105692^{\mathrm{T}}$ were streaked at the right angle of Actinobacterial cultures. Plates were incubated at $28^{\circ} \mathrm{C}$ for $48 \mathrm{hrs}$ and the zone of inhibition was recorded. ISP 2 plates without Actinobacteria isolates but streaked with the same stock of pathogens were used as control.

2.5. Crude Extracts Preparation and Screening for Secondary Antimicrobial Metabolites. Eighty-seven Actinobacteria isolates were subjected to subsequent investigation by antimicrobial screening of their secondary metabolites. The method of Thakur et al. [31] was modified for screening bioactive antimicrobial metabolites. The same pathogens used during preliminary screening were used for this screening. These pathogens were cultured overnight at $37^{\circ} \mathrm{C}$ at $200 \mathrm{rpm}$ in nutrient broth. The cultures were diluted with their respective media to $0.8-1.2 \times 10^{6} \mathrm{CFU} / \mathrm{mL}$, and $100 \mu \mathrm{L}$ aliquots of this inoculum were transferred to nutrient agar media.

The fermentation medium used was FM3 [32]; the medium was autoclaved at $121^{\circ} \mathrm{C}$ for $20 \mathrm{~min}$. Each of the 87 purified isolates was transferred to a test tube $(30 \mathrm{~mm}$ $\times 200 \mathrm{~mm}$ ) containing $20 \mathrm{~mL}$ of the relevant fermentation medium and cultured at $200 \mathrm{rpm}$, at an angle of $45^{\circ}$, for 7-10 days at $28^{\circ} \mathrm{C}$. The resulting fermentation media obtained from each of the isolates were separated from the mycelium by centrifugation at $10,000 \mathrm{rpm}$ at $4^{\circ} \mathrm{C}$ for $15 \mathrm{~min}$. The supernatants were filtered (Whatman number 1 filter paper) and tested for extracellular antimicrobial activity against different target pathogens using agar well diffusion method [33]. A sterile cork borer was used to puncture well in appropriate agar medium plates previously seeded with one of the pathogen strains. One hundred $\mu \mathrm{L}$ from the fermentation supernatant of the isolates was added to each of the wells. The inoculated plates were kept at $4^{\circ} \mathrm{C}$ for at least $2 \mathrm{hrs}$ to allow the diffusion of produced antimicrobial metabolites. The diameters of inhibition are determined after $24 \mathrm{hrs}$ of incubation at $37^{\circ} \mathrm{C}$ and verified active substance extraction. Each experiment was repeated three times and average value of inhibitory zones was reported. Blank wells without the fermentation medium were taken as control.

\subsection{Molecular Identification of Actinobacteria Isolates}

2.6.1. Genomic DNA Extraction and PCR Amplification of $16 S$ rDNA. Genomic DNA extractions for 87 isolates of Actinobacteria were performed as described by Hong et al. [1]. The primer pair 27F-1492R $[1,28]$ was used for PCR amplification using the Kyratec PCR Supercycler (Kyratec, Australia). The PCR reaction mixture that consisted of 20$200 \mathrm{ng}$ bacteria genomic DNA, $10.0 \mu \mathrm{L}$ of $2 \mathrm{X}$ Prime Taq Premix (Genet Bio, Korea), 10 pmoles primer 27F and primer $1492 \mathrm{R}$, and sterile ultrapure water was added to final volume of $20 \mu \mathrm{L}$. The cycling parameters were as described by Hong et al. [1].

2.6.2. Phylogenetic Analysis of $16 S \mathrm{r}$ RNA Gene Sequences. The PCR products were purified using the GeneAll Expin Gel SV purification kit (GeneAll, South Korea); and then molecular cloning was performed using the InsTAclone PCR cloning kit (Thermo Scientific, USA) according to the manufacturer's protocols. The insertions were verified using colony-PCR and colonies with transformations were preceded to plasmid DNA extraction using the Eppendorf FastPlasmid Minikit. Purified plasmid DNA served as templates for PCR to confirm the insertion of the gene of interest. Plasmid DNAs were sequenced using an ABI PRISM 3100 DNA sequencer (Applied Biosystems, USA).

The cloned 16S rRNA gene sequences were aligned manually using sequences from the closest related genera retrieved from the GenBank/EMBL/DDBJ databases using CLUSTAL$\mathrm{X}$ [34]. The alignment was manually verified and adjusted prior to the construction of a phylogenetic tree. The calculation for the level of sequence similarity was performed using the EzTaxon-e server (http://eztaxon-e.ezbiocloud.net/) [35]. The phylogenetic tree was inferred using the neighbor joining algorithms [36] via molecular evolutionary genetic analysis (MEGA version 5.2) [37]. The stabilities of the resultant tree topologies were evaluated using bootstrap analysis [38]. The pairwise distances between sequences were generated using Kimura's 2-parameter model [39].

2.6.3. DNA-DNA Hybridization for Putative Novel Isolates. Biomass for chemotaxonomic studies was obtained after growing in tryptic soy broth (TSB) at $28^{\circ} \mathrm{C}$ for 7 days on a rotary shaker. The extraction of genomic DNA for DNA-DNA hybridization of putative novel isolates (MUSC $115^{\mathrm{T}}$ and MUSC $135^{\mathrm{T}}$ ) and their closely related type strains was carried out by the identification service of the DSMZ, Braunschweig, Germany. Genomic DNA extractions from the isolates were performed as described by Cashion et al. [40]. DNA-DNA hybridization was carried out as described by de Ley et al. [41] under consideration of the modifications described by Huss et al. [42] using a model Cary 100 Bio UV/VISspectrophotometer equipped with a Peltier-thermostatted $6 \times$ 6 multicell changer and a temperature controller with in situ temperature probe (Varian). 
TABLE 1: PCR primers used in this study.

\begin{tabular}{|c|c|c|c|c|}
\hline Primer name & Sequence $\left(5^{\prime}-3^{\prime}\right)$ & Target gene & Product size (bp) & Reference \\
\hline $27 \mathrm{~F}$ & GTTTGATCCTGGCTCAG & \multirow{2}{*}{ 16S rRNA } & \multirow{2}{*}{$1400-1500$} & \multirow{2}{*}[1,28]{} \\
\hline $1492 \mathrm{R}$ & TACGGCTACCTTGTTACGACTT & & & \\
\hline $\mathrm{K} 1 \mathrm{~F}$ & TSAAGTCSAACATCGGBCA & \multirow{2}{*}{ PKS-I } & \multirow{2}{*}{$1200-1400$} & \multirow{2}{*}[29]{} \\
\hline M6R & CGCAGGTTSCSGTACCAGTA & & & \\
\hline $\mathrm{KS} \alpha$ & TSGCSTGCTTGGAYGCSATC & \multirow{2}{*}{ PKS-II } & \multirow{2}{*}{600} & \multirow{2}{*}[30]{} \\
\hline $\mathrm{KS} \beta$ & TGGAANCCGCCGAABCCTCT & & & \\
\hline $\mathrm{A} 3 \mathrm{~F}$ & GCSTACSYSATSTACACSTCSGG & \multirow{2}{*}{ NRPS } & \multirow{2}{*}{$700-800$} & \multirow{2}{*}[29]{} \\
\hline A7R & SASGTCVCCSGTSCGGTAS & & & \\
\hline
\end{tabular}

2.6.4. PCR Detection of PKS-I, PKS-II, and NRPS Sequences. Three sets of degenerate primers were used for the amplification of genes encoding polyketide synthases I and II (PKS-I and PKS-II) and nonribosomal peptide synthetases (NRPS) (Table 1). The PCR reaction mixture that consisted of 20-200 ng bacteria genomic DNA, $10.0 \mu \mathrm{L}$ of $2 \mathrm{X}$ Prime Taq Premix (Genet Bio, Korea), 10 pmoles of different primer sets (Table 1), and sterile ultrapure water was added to final volume of $20 \mu \mathrm{L}$. The PCR was performed using the Kyratec PCR Supercycler (Kyratec, Australia) with the following cycling conditions: (i) $94^{\circ} \mathrm{C}$ for $5 \mathrm{~min}$; (ii) 30 cycles of $94^{\circ} \mathrm{C}$ for $1 \mathrm{~min}, 57^{\circ} \mathrm{C}$ (for $\mathrm{K} 1 \mathrm{~F}-\mathrm{M} 6 \mathrm{R}$ and $\mathrm{KS} \alpha-\mathrm{KS} \beta$ ) or $62^{\circ} \mathrm{C}$ (for A3F-A7R) for $1 \mathrm{~min}$, and $72^{\circ} \mathrm{C}$ for $2 \mathrm{~min}$; and (iii) $72^{\circ} \mathrm{C}$ for $5 \mathrm{~min}$. The PCR amplification products were resolved using electrophoresis in $1.5 \%$ agarose gel (Promega, USA) and stained with ethidium bromide $\left(0.5 \mu \mathrm{g} \mathrm{mL}^{-1}\right)$ and viewed using Molecular Imager Chemidoc XRS System (Biorad, USA).

\section{Results and Discussion}

3.1. Selective Isolation of Actinobacteria. Based on the distinct morphology of Actinobacteria isolates on the media plate, a total of 87 isolates of Actinobacteria were successfully isolated from four composite mangrove sediments collected from Tanjung Lumpur of the State of Pahang, Malaysia. Sediments samples were named as TLS1, TLS2, TLS3, and TLS4 that were contributing to $47,12,15$, and 13 isolates, respectively, of the total number of isolates. Eighty-seven isolates were isolated from 6 types of isolation media supplemented with cycloheximide, nystatin, and nalidixic acid; these media are, namely, SCA $(n=35)$, ISP $2(n=18)$, ISP $7(n=18)$, AIA $(n=11)$, NA $(n=3)$, and SA $(n=2)$. These results indicated that starch casein agar (SCA) was the most suitable medium for isolating Actinobacteria in this study, and this result is in agreement with others [43].

3.2. Diversity of Actinobacteria Isolates. Eighty-seven Actinobacteria isolates were identified to the genera level based on the molecular and morphological characteristics. The $16 \mathrm{~S}$ rRNA gene sequences of these isolates were compared with 16S rRNA sequences of type strains retrieved from DDBJ/EMBL/GenBank. Results showed that Actinobacteria isolated in this study exhibited high level of diversity, as the 87 isolates were distributed among 5 suborders: Streptomycineae $(n=53)$, Micrococcineae $(n=16)$, Corynebacterineae $(n=$ 16), Micromonosporineae $(n=1)$, and Propionibacterineae $(n=1)$ within the phylum Actinobacteria. A total of 11 genera were identified and each genus was distinguished by its $16 \mathrm{~S}$ rRNA gene sequences. Of the 87 isolates, $59.8 \%$ ( $n=52$ ) of the isolates were assigned as genus Streptomyces, $14.9 \%(n=13)$ as the genus Mycobacterium, and the remaining isolates as Leifsonia $(n=6)$, Microbacterium $(n=$ $4)$, Sinomonas $(n=4)$, Nocardia $(n=2)$, Terrabacter $(n=2)$, Gordonia $(n=1)$, Micromonospora $(n=1)$, Nocardioides $(n=1)$, and Streptacidiphilus $(n=1)$. In this study, it is evident that some genera not commonly found in the mangrove environment were discovered, such as Streptacidiphilus, Sinomonas, Terrabacter, and Leifsonia. So far, the different species of Streptacidiphilus were isolated from area such as Pinus soils [44], acidic rhizosphere soil [45], and rice field soil [46], while Sinomonas was mostly discovered in forest soils [47], polluted forest soil [48], and volcanic soil [49].

The isolation of Actinobacteria from eleven genera showed a wide distribution of Actinobacteria in mangrove environment, especially in soil and sediments [1]. The presence of predominant number of Streptomyces isolates (59.8\%) in this study is in agreement with results reported by Hong et al. [1] which isolated substantial Streptomyces isolates from mangrove soils in China. The identification of substantial number of Streptomyces isolates was extremely important for the antimicrobial bioactivities screening in this study, as this genus is proven to be the prolific producers of novel antibiotics $[50,51]$, with approximately $75 \%$ of commercially useful antibiotics being derived from Streptomyces [5].

The analysis of $16 \mathrm{~S}$ rRNA sequences is used to determine higher taxonomic relationships of Actinobacteria [52, 53]. In this study, the $16 \mathrm{~S}$ rRNA gene sequences were used to build a phylogenetic tree for 35 isolates of non-Streptomyces isolates together with their closely related type strains (Figure 1), whereas another phylogenetic tree was built for 52 isolates assigned to genus Streptomyces and their closely related type strains (Figure 2). The percentages of the $16 \mathrm{~S}$ rRNA gene sequence similarities (95.1 to $100 \%$ ) of these isolates to the closest type strains are shown in Table 2. The taxonomic studies showed that some isolates were highly potential to be assigned as novel genus or species based on the phylogenetic and pairwise comparison of $16 \mathrm{~S}$ rRNA gene sequences of 


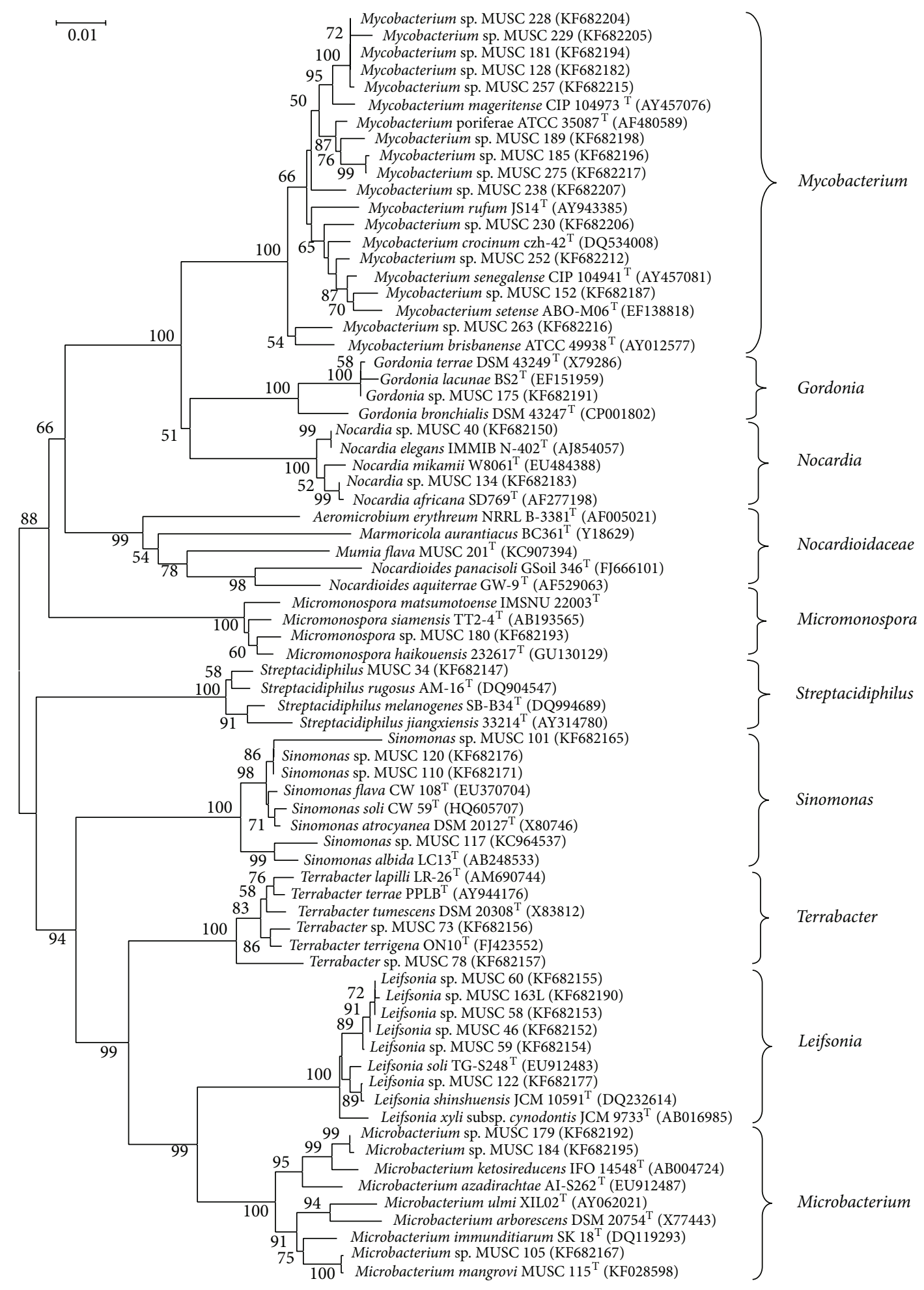

FIGURE 1: Phylogenetic tree based on 16S rRNA sequences using neighbour-joining method for 35 isolates of non-Streptomyces Actinobacteria and their closely related type strains. Bootstrap values (>40\%) based on 1000 resampled datasets are shown at branch nodes. Bar, 1 substitution per 100 nucleotide positions. 


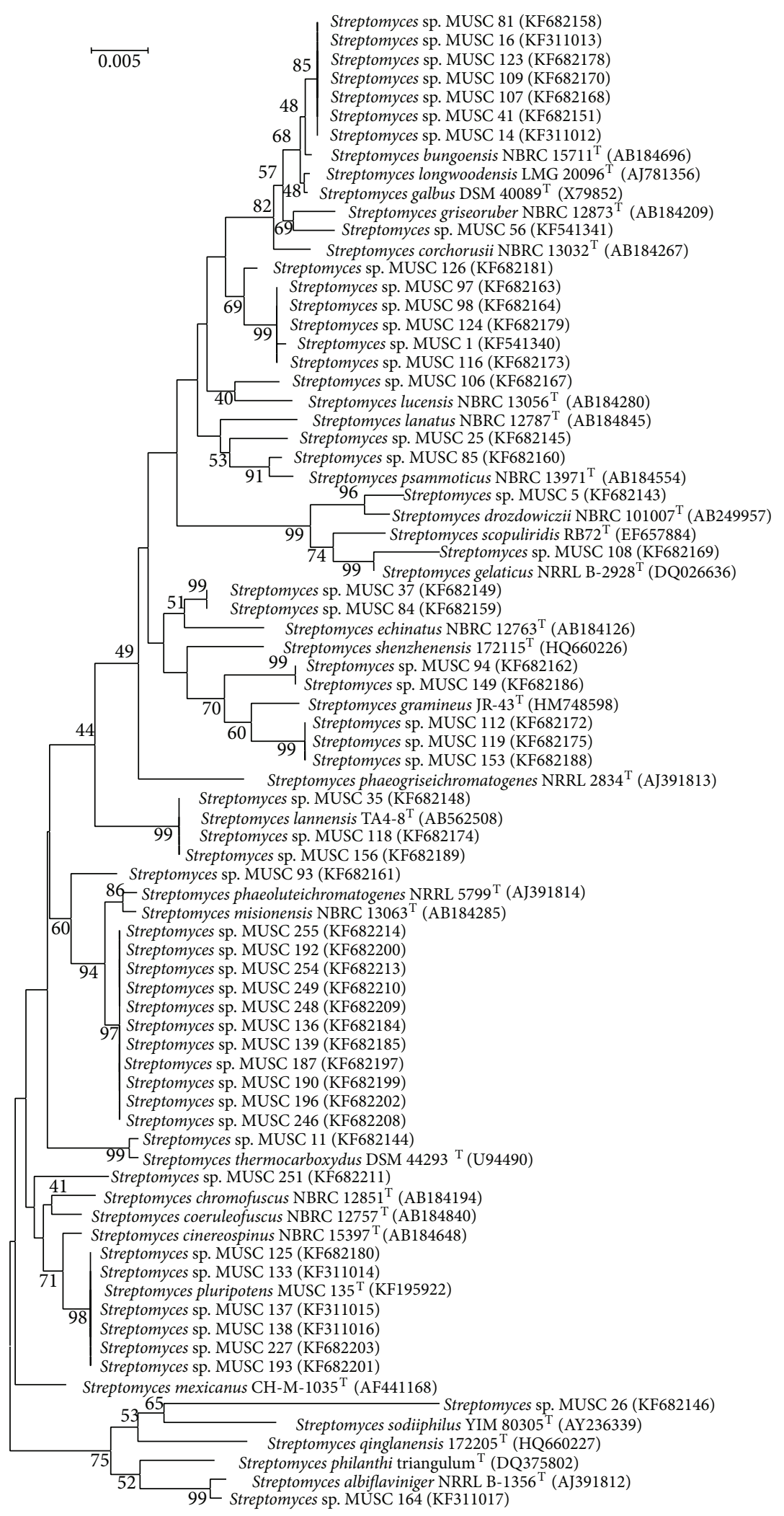

FIGURE 2: Phylogenetic tree based on $16 \mathrm{~S}$ rRNA sequences using neighbour-joining method for 52 isolates of Streptomyces sp. and their closely related type strains. Bootstrap values $(>40 \%)$ based on 1000 resampled datasets are shown at branch nodes. Bar, 5 substitutions per 1000 nucleotide positions. 
the novel isolates with the type strains. Four isolates from three genera (Sinomonas, Microbacterium, and Streptomyces) showed high possibilities of novel species discovery and one isolate (MUSC $201^{\mathrm{T}}$ ) was identified as a novel genus in the family Nocardioidaceae.

Isolate MUSC $201^{\mathrm{T}}$ was obtained from soil sample MUSC-TLS4 $\left(3^{\circ} 48^{\prime} 21.3^{\prime \prime} \mathrm{N} 103^{\circ} 20^{\prime} 3.3^{\prime \prime} \mathrm{E}\right)$ pretreated with wet heat method [18]; the mixture was spread onto ISP 2 supplemented with cycloheximide and nystatin and incubated at $28^{\circ} \mathrm{C}$ for 7 days. The $16 \mathrm{~S}$ rRNA gene sequences were determined for isolate MUSC $201^{\mathrm{T}}$ (1486 bp) [GenBank: KC907394]. The comparison of isolate MUSC $201^{\mathrm{T}}$ to the closely related phylogenetic neighbors indicated that it was closely related to the type strains of different genera within the family Nocardioidaceae: Nocardioides ( $95.1 \%$ to $91.9 \%$ similarity), Aeromicrobium (94.6 to $92.7 \%$ similarity), Marmoricola ( $93.1 \%$ to $92.5 \%$ similarity), and Kribbella ( $92.4 \%$ to $91.5 \%$ similarity). Isolate MUSC $201^{\mathrm{T}}$ formed a distinct monophyletic clade within the family Nocardioidaceae (Figure 1), most closely related to type strain Nocardioides panacisoli GSoil $346^{\mathrm{T}}$, and Actinobacteria were isolated from soil of ginseng field [54] at high bootstrap value of $78 \%$. Isolate MUSC $201^{\mathrm{T}}$ had low $16 \mathrm{~S}$ rRNA gene sequence similarities with members of the closest related genus Nocardioides (94.195.1\%) and was separated from them by a long evolutionary distance in the phylogenetic tree (Figure 1). On the basis of phylogenetic, genotypic, and chemotaxonomic profiles, isolate MUSC $201^{\mathrm{T}}$ is truly different from any existing genera in the family Nocardioidaceae; hence, isolate MUSC $201^{\mathrm{T}}$ represented a novel species in a new genus of the family Nocardioidaceae, for which the name "Mumia flava gen. nov., sp. nov." is proposed and published [55].

The Microbacterium sp. isolates (MUSC 179, MUSC 184, MUSC 105, and MUSC $115^{\mathrm{T}}$ ) formed distinct phylogenetic clade in the neighbour-joining tree but were separated from other members of the genus Microbacterium (Figure 1). Isolates MUSC 179 and MUSC 184 were closely related to Microbacterium ketosireducens IFO $14548^{\mathrm{T}}$ (97.7\% similarity) and Microbacterium azadirachtae AI-S262 ${ }^{\mathrm{T}}$ (97.7\% similarity) (Table 2). Another 2 isolates (MUSC 105 and MUSC 115) were assigned to Microbacterium immunditiarum SK $18^{\mathrm{T}}$, with 98.0 and $98.1 \%$ similarity (Table 2). Isolate MUSC $115^{\mathrm{T}}$ was selected for further analysis to determine its potential as novel species.

Isolate MUSC $115^{\mathrm{T}}$ was obtained from soil sample MUSC-TLS1 $\left(3^{\circ} 48^{\prime} 3.2^{\prime \prime} \mathrm{N} 103^{\circ} 20^{\prime} 11.0^{\prime \prime} \mathrm{E}\right)$ pretreated with wet heat method [18]; the mixture was spread onto starch casein agar. The $16 \mathrm{~S}$ rRNA gene sequence was established for strain MUSC $115^{\mathrm{T}}$ (1484 bp) [GenBank: KF028598]. Phylogenetic analysis of isolate MUSC $115^{\mathrm{T}}$ indicated that it formed a subclade with Microbacterium immunditiarum SK $18^{\mathrm{T}}$ at high bootstrap supported value of 75\% (Figure 1). Pairwise comparison of the $16 \mathrm{~S}$ rRNA gene sequences from isolate MUSC $115^{\mathrm{T}}$ showed similarities to Microbacterium immunditiarum SK $18^{\mathrm{T}}$, Microbacterium ulmi XIL02 ${ }^{\mathrm{T}}$, and Microbacterium arborescens $\mathrm{NBRC} 3750^{\mathrm{T}}$ at $98.1,97.8$, and $97.5 \%$, respectively. The DNA-DNA relatedness values between strain
MUSC $115^{\mathrm{T}}$ and Microbacterium immunditiarum SK $18^{\mathrm{T}}$ $(23.6 \pm 0.5 \%)$, Microbacterium ulmi XIL02 ${ }^{\mathrm{T}}(26.2 \pm 2.7 \%)$, and Microbacterium arborescens DSM $20754^{\mathrm{T}}(16.3 \pm 1.1 \%)$ were significantly lower than $70 \%$, the threshold value for the delineation of genomic species [56]. The DDH results suggested that strain MUSC $115^{\mathrm{T}}$ does not belong to any of these species. The comparison of phenotypic characterization between isolate MUSC $115^{\mathrm{T}}$ with its closely related type strains showed substantial differences between them [57]. Hence, isolate MUSC $115^{\mathrm{T}}$ represented a novel species within the genus Microbacterium with lineages distinct from other members of the genus Microbacterium (Figure 1), proposed as "Microbacterium mangrovi sp. nov." [57].

The Sinomonas sp. isolates (MUSC 101, MUSC 110, MUSC 117, and MUSC 120) formed a distinct phylogenetic clade that was distinct from other members of the phylum Actinobacteria with high bootstrap value (100\%) (Figure 1). Two isolates (MUSC 101 and MUSC 120) were assigned to Sinomonas soli, with 96.8 and $99.1 \%$ similarity (Table 2 ). Isolate MUSC 101 was separated from the rest of the isolates by a long evolutionary distance in the phylogenetic tree; this association is supported by bootstrap value of $86 \%$ (Figure 1 ). The 16S rRNA gene sequence similarity value was lower than $97 \%$, which is considered to be the cutoff value for species identity [58]. Therefore, isolate MUSC 101 could serve as a highly potential candidate as a novel species of the genus Sinomonas. Phylogenetic analysis of isolates Sinomonas sp. MUSC 117 indicated that it formed a distinct clade with type strains from genus Sinomonas at high bootstrap value of 100\% (Figure 1). Isolate Sinomonas sp. MUSC 117 formed subclade with Sinomonas albida, an association supported by robust bootstrap value of $99 \%$ (Figure 1). The pairwise comparison of $16 \mathrm{~S}$ rRNA gene sequence analysis showed that isolate MUSC 117 is assigned to type strains Sinomonas atrocyanea, Sinomonas albida, and Sinomonas soli with 98, 97.9, and $97.8 \%$ similarity, respectively. These $16 \mathrm{~S}$ rRNA gene similarity values are less than the similarity values between closely related Sinomonas species, such as S. atrocyanea and its closest related species, S. soli (99.5\% similarity). Therefore, isolate MUSC 117 serves as a good candidate for novel species in the genus Sinomonas.

3.3. Diversity and Phylogeny of Bioactive Actinobacteria Isolates. Of 87 isolates, 9 isolates which belonged to genus Streptomyces were producing bioactive metabolites (Table 2). The relationships between taxonomic and metabolic diversity are being highlighted for these bioactive isolates. As more novel Actinobacteria isolated from various environments are able to offer precious sources of new bioactive metabolites and compounds [59-61], the analysis of the 16S rRNA gene sequences of the bioactive isolates showed that isolates Streptomyces sp. MUSC 14 and Streptomyces sp. MUSC 16 shared the highest similarities to Streptomyces bungoensis NBRC $15711^{\mathrm{T}}$ with 99.5 to $99.4 \%$ identities (Table 2). They formed distinct subclade with Streptomyces bungoensis NBRC $15711^{\mathrm{T}}$ at $48 \%$ bootstrap value (Figure 2). Isolate MUSC 164 showed $98.4 \%$ identities to Streptomyces albiflaviniger NRRL 


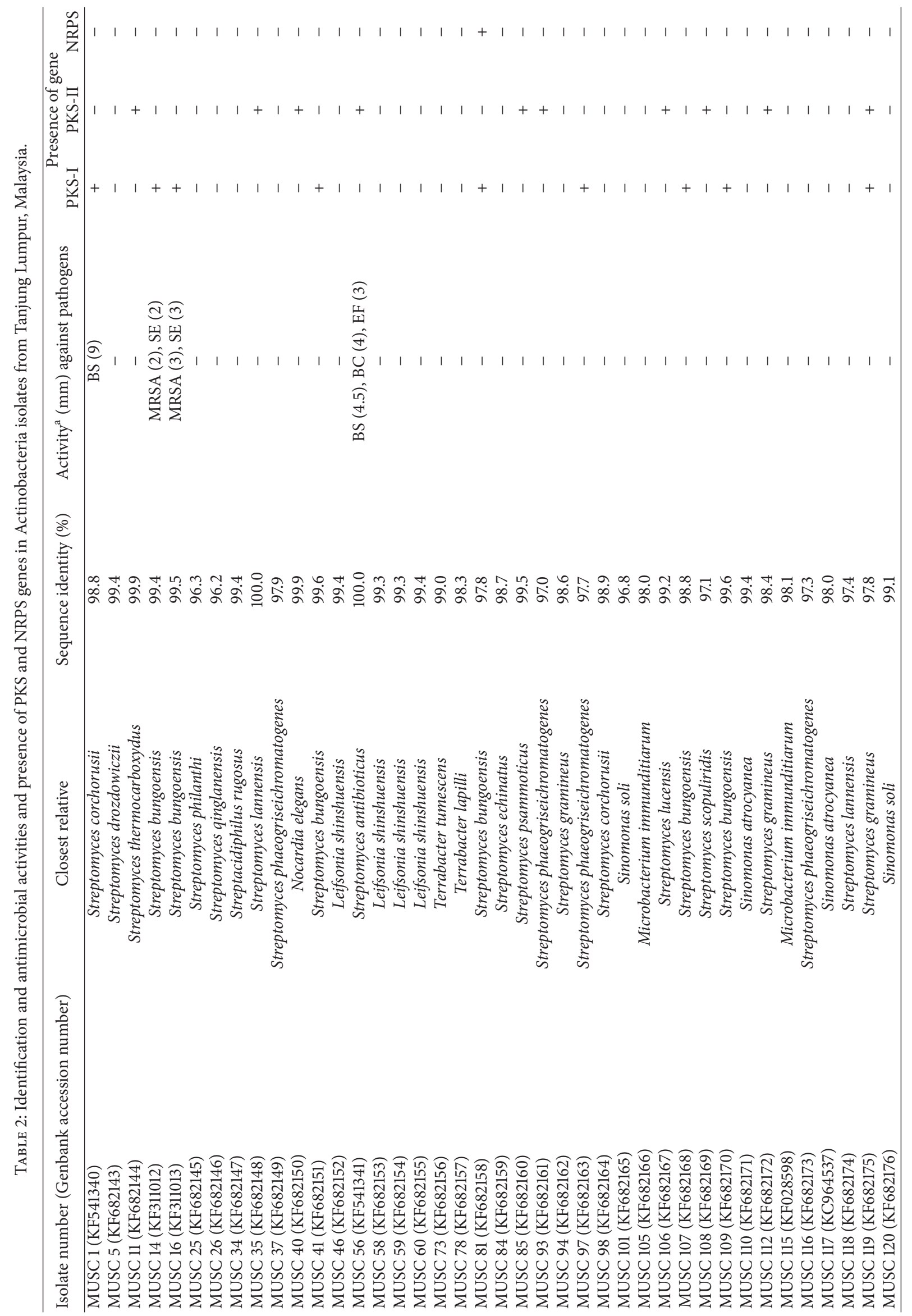




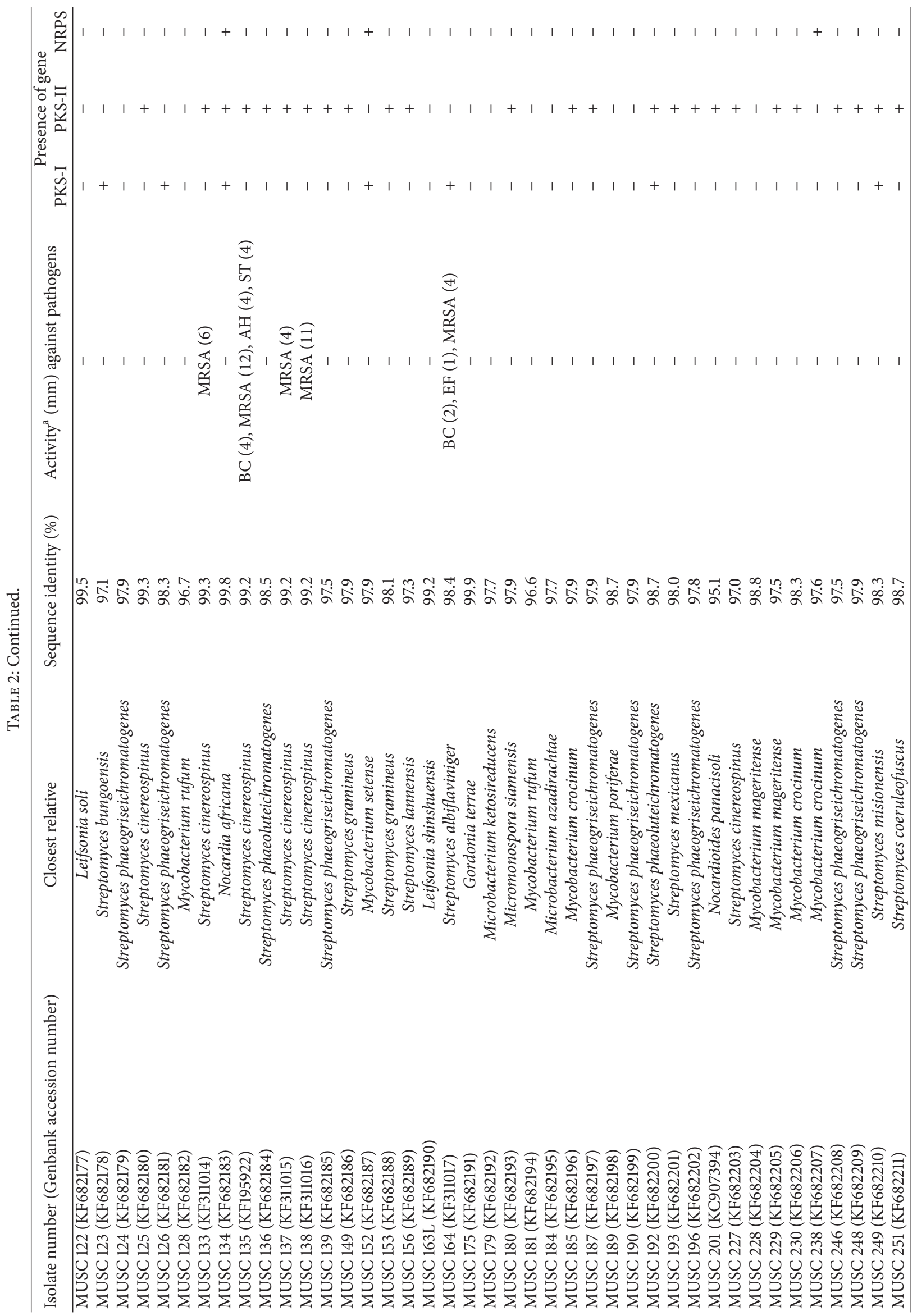




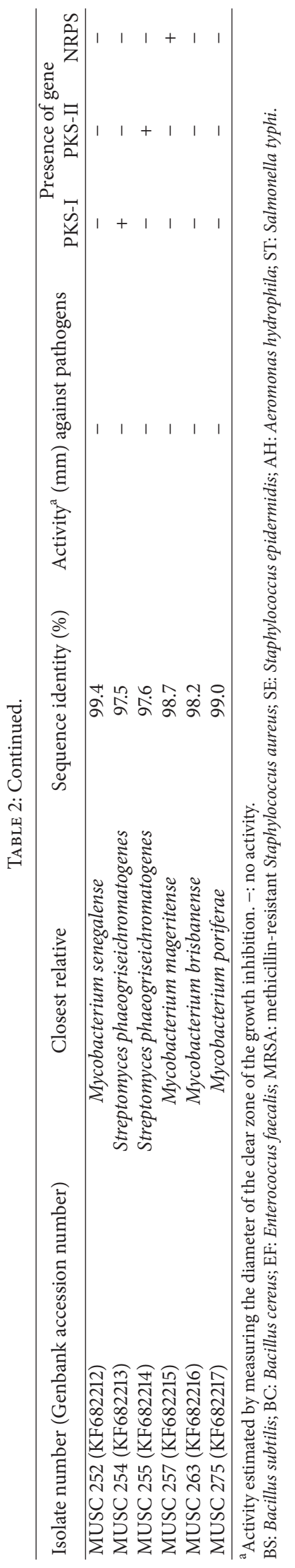


B-1356 ${ }^{\mathrm{T}}$ (Table 2) and they formed a monophyletic clade at 99\% bootstrap value (Figure 2).

Isolates Streptomyces sp. MUSC 133, MUSC $135^{\mathrm{T}}$, MUSC 137, and MUSC 138 exhibited the highest similarities to sequences of type strain Streptomyces cinereospinus with 99.2 to $99.3 \%$ identities (Table 2). The phylogenetic analysis showed that isolates MUSC 133, MUSC $135^{\mathrm{T}}$, MUSC 137, and MUSC 138 formed a distinct clade with type strains Streptomyces cinereospinus NBRC $15397^{\mathrm{T}}$ at bootstrap value of $71 \%$ (Figure 2). Furthermore, these Streptomyces isolates (MUSC 133, MUSC 135 ${ }^{\mathrm{T}}$, MUSC 137, and MUSC 138) formed a distinct monophyletic subclade supported by robust bootstrap values of $98 \%$ (Figure 2). The 16S rRNA gene sequence similarities between isolate MUSC $135^{\mathrm{T}}$ and isolates MUSC 133, MUSC 137, and MUSC 138 were 100, 100, and $99.9 \%$, respectively. Therefore, isolates MUSC 133, MUSC $135^{\mathrm{T}}$, MUSC 137, and MUSC 138 should be considered as the same species. Isolate MUSC $135^{\mathrm{T}}$ was chosen as the representative for subsequent characterization as this isolate could produce diverse and potent antimicrobial secondary metabolites. Isolate MUSC $135^{\mathrm{T}}$ showed similarities to type strains Streptomyces cinereospinus NBRC $15397^{\mathrm{T}}$, Streptomyces mexicanus $\mathrm{CH}-\mathrm{M}-1035^{\mathrm{T}}$, and Streptomyces coeruleofuscus NBRC $12757^{\mathrm{T}}$ with 99.18, 99.17, and 98.97\% similarity, respectively (Table 2). These similarities values are lower as compared to the similarity value of type strain Streptomyces cinereospinus NBRC $15397^{\mathrm{T}}$ to its closest related species Streptomyces coeruleofuscus NBRC $12757^{\mathrm{T}}$ (99.4\% similarity). Furthermore, the DNA-DNA relatedness values between strain MUSC $135^{\mathrm{T}}$ and Streptomyces cinereospinus NBRC $15397^{\mathrm{T}}(26.3 \pm 2.1 \%)$, coeruleofuscus NBRC $12757^{\mathrm{T}}(49.5 \pm$ $2.9 \%)$, and Streptomyces mexicanus NBRC $100915^{\mathrm{T}}$ (49.6 \pm $2.5 \%$ ) were notably below $70 \%$, the threshold value for the delineation of genomic species [56]. Polyphasic characterizations results supported the observation that isolate Streptomyces sp. MUSC $135^{\mathrm{T}}$ represented a novel species, proposed as "Streptomyces pluripotens sp. nov.", [62] that exhibited merits in producing antimicrobial secondary metabolites.

3.4. Antibacterial Potential of Isolates. The 87 isolates were preceded to preliminary screening for antimicrobial activity against 12 pathogens by using the cross streak method [31]. Of 87 isolates, 48 isolates (55.2\%) exhibited inhibitory against at least 1 pathogen used in this study. Of 48 isolates, $20.8 \%$ $(n=10)$ exhibited inhibitory activity against Gram negative bacteria and 2.1\% $(n=1)$ inhibited Gram positive bacteria. The remaining $77.1 \%(n=37)$ showed excellent inhibition towards both Gram negative and Gram positive bacteria.

3.5. Antimicrobial Activity of Culture Extracts from Mangrove Actinobacteria Isolates. The 87 Actinobacteria isolates were subjected to subsequent investigation by antimicrobial screening of their secondary metabolites. The secondary metabolites of these isolates were tested for antimicrobial activities against the same group of 12 pathogenic bacteria used during preliminary screening. Of 87 isolates, 9 isolates (10.3\%) which belonged to the genus Streptomyces were exhibiting activity against at least one of the pathogenic bacteria tested. Of the 9 isolates, $55.6 \%(n=5)$ were active against more than 1 pathogen. Two isolates (MUSC 14 and MUSC 16) were inhibiting 2 pathogens. Three isolates (MUSC 56, MUSC 135, and MUSC 164) exhibited broad spectrum of antibacterial activity, with MUSC 135 showing the strongest inhibition effects against MRSA (inhibition zone of $12 \mathrm{~mm}$ ), Bacillus cereus ( $4 \mathrm{~mm})$, Acinetobacter calcoaceticus ( $4 \mathrm{~mm})$, and Salmonella typhi $(4 \mathrm{~mm}$ ) in this study (Table 2). The strong inhibitory activities of these Actinobacteria isolates towards an array of pathogens are a good indicator that these isolates could be the potential candidates for production of highly valuable bioactive secondary metabolites. Some of the bioactive metabolites are currently being chemically analyzed to identify the novelty of the active compounds.

The identification of Streptomyces as the most bioactive genus in this study is in line with other researchers [1] as Streptomyces has the ability to catabolize a wide range of compounds and produce secondary metabolites with diverse biological activities and chemical structure [4]. Streptomyces is the largest genus of the Actinobacteria and over two-thirds of all natural antibiotics are derived from this group of bacteria [5]. Streptomyces has a huge biosynthetic potential that remains unchallenged among other microbial groups. This is proven as some Streptomyces species, whose biosynthetic repertoire was considered to be only three to five secondary metabolites, in fact possess more than 20 genomic regions encoding known or predicted biosynthetic pathways $[63,64]$.

Total of 10\% (9/87) of Actinobacteria isolates exhibited antimicrobial properties in this study. These results indicated that Actinobacteria are still capable of producing highly bioactive metabolites and continued to provide high quality biological material for drug discovery. Nevertheless, to increase the chances of discovering bioactive isolates in future study, new targets could be used to detect more activities such as antimicrobial and cytotoxic activities [65], as the discovery of novel microbial natural products is encouraged not only by the quality of biological material but also by the innovation and sensitivity of the screening models used [1].

3.6. Detection of PKS and NRPS Genes in Actinobacteria Isolates. Many Actinobacterial isolates from marine environments contain polyketide synthetase (PKS) and nonribosomal polyketide synthetase (NRPS) pathways, the characteristics of secondary metabolite production [16]. In this study, eighty-seven isolates were screened for the presence of PKSI, PKS-II, and NRPS gene sequences by specific amplification of chromosomal DNA with primer sets K1F-M6R, KS $\alpha$ $\mathrm{KS} \beta$, and A3F-A7R (Table 1). The amplification products were examined by $1 \%$ agarose gel electrophoresis, and bands of 1200 to $1400 \mathrm{bp}, 600 \mathrm{bp}$, and 700 to $800 \mathrm{bp}$ were identified as products of PKS-I, PKS-II, and NRPS genes, respectively (Table 1). Of 87 isolates tested for the presence of PKS and NRPS genes, 52 isolates (59.7\%) exhibited at least one type of biosynthetic sequences. PKS-II genes were the most frequent as it is detected in $42.5 \%(n=37)$ of the isolates. PKS-I genes were detected in $19.5 \%$ of the isolates $(n=17)$, and NRPS genes were exhibited by only 5 isolates (5.7\%). The only 
isolate that contained all of the biosynthetic genes (PKS-I, PKS-II, and NRPS) used is MUSC 134, a Nocardia species that is closely related to Nocardia Africana at $99.8 \%$ similarity. Isolates MUSC 119, MUSC 192, and MUSC 249 contained both of the PKS-I and PKS-II genes, whereas isolates MUSC 81 and MUSC 152 showed positive amplification of both PKSI and NRPS genes products.

The percentage of bioactive isolates $(10.3 \%)$ detected in this study is relatively low as compared to the percentage of isolates with at least one type of biosynthetic sequences (59.7\%). This showed that the fermentation media (FM3) used may not be able to provide the nutrients and conditions needed to stimulate secondary metabolite production in many of the mangrove Actinobacteria isolates in this study. Therefore, the PCR detection of polyketide synthase types I and II and the nonribosomal peptide synthetase genes is vital to discover the potential of these isolates to produce valuable secondary metabolites. Some of the secondary metabolite biosynthetic gene clusters appear to be nonactive or silent under standard culture conditions and they may require some specific triggers to be activated [66]; these data exhibited that the nonbioactive isolates hold the genetic capability to produce useful secondary metabolites if they were cultivated under the appropriate conditions. As rare taxa such as the Nocardioides (isolate MUSC $201^{\mathrm{T}}$ ) showed biosynthetic potential by carrying the PKS-II genes, shedding light on the possibility to serve as a source of natural products, but even this genus has not been shown to produce any natural products yet.

The absence of amplification products from some of the isolates may reveal the lack of PKS-I, PKS-II, and NRPS genes. However, the negative results could be caused by the types of degenerate primers used, which were not suitable for amplifying these genes [67], especially for the low detection rate of NRPS genes in this study. Moreover, it is reported that not all of the NRPS genes are involved in the biosynthesis of bioactive secondary metabolites, as these genes could be responsible in functionality of the bacteria such as quorum sensing [68] or iron metabolism [30]. The high rate of detection of PKS-I and PKS-II genes in the isolates tested was mostly Streptomyces, providing strong evidence for the high potential of Streptomyces to produce high number of biologically active metabolites. Therefore, the molecular screening of Actinobacteria isolates for genes encoding biosynthesis of bioactive compounds is still an effective and valuable approach for preselecting isolates for useful secondary metabolites production [29, 67, 69-73].

\section{Conclusions}

In conclusion, this study performed a comprehensive investigation into the diversity, phylogeny, and biosynthetic and antimicrobial potential of Actinobacteria isolated from tropical mangrove sediments in east coast of Peninsular Malaysia. A substantial diversity of Actinobacteria isolates was isolated from mangrove habitats, and it is apparent that isolates from genera such as Sinomonas, Microbacterium, and Streptomyces could merit novel species status. Many of the Actinobacteria isolates are producing bioactive secondary metabolites or possess detectable biosynthetic genes, indicating that mangrove habitats are a valuable source of discovery for novel Actinobacteria with promising potential to produce highly bioactive antimicrobial metabolites that could have important value in drug discovery programs.

\section{Conflict of Interests}

The authors declare that they have no conflict of interests.

\section{Acknowledgments}

This work was supported by the High Impact Research Grant (UM-MOHE HIR Nature Microbiome Grant no. H-50001A000027) of University of Malaya awarded to Dr. Chan Kok-Gan, also MOHE FRGS Grant (Vote no. 2500110), and External Industry Grant (Vote no. GBA-808138) awarded to Dr. Learn-Han Lee.

\section{References}

[1] K. Hong, A. Gao, Q. Xie et al., "Correction: hong, K. et al. Actinomycetes for Marine Drug discovery isolated from mangrove soils and plants in China (Marine Drugs (2009) 7, (24-44))," Marine Drugs, vol. 7, no. 4, pp. 495-496, 2009.

[2] K. Goshi, T. Uchida, A. Lezhava et al., "Cloning and analysis of the telomere and terminal inverted repeat of the linear chromosome of Streptomyces griseus," Journal of Bacteriology, vol. 184, no. 12, pp. 3411-3415, 2002.

[3] P. C. Y. Woo, S. K. P. Lau, Y. Huang, and K.-Y. Yuen, “Genomic evidence for antibiotic resistance genes of actinomycetes as origins of antibiotic resistance genes in pathogenic bacteria simply because actinomycetes are more ancestral than pathogenic bacteria," Medical Hypotheses, vol. 67, no. 6, pp. 1297-1304, 2006.

[4] M. V. Arasu, V. Duraipandiyan, P. Agastian, and S. Ignacimuthu, "Antimicrobial activity of Streptomyces spp. ERI-26 recovered from Western Ghats of Tamil Nadu," Journal de Mycologie Medicale, vol. 18, no. 3, pp. 147-153, 2008.

[5] J. Bérdy, "Bioactive microbial metabolites," Journal of Antibiotics, vol. 58, no. 4, pp. 1-26, 2005.

[6] W. Fenical, D. Baden, M. Burg et al., From Monsoons to Microbes: Understanding the Ocean's Role in Human Health, National Academy Press, Washington, DC, USA, 1999.

[7] K. S. Lam, "New aspects of natural products in drug discovery," Trends in Microbiology, vol. 15, no. 6, pp. 279-289, 2007.

[8] D. J. Newman and G. M. Cragg, "Natural products as sources of new drugs over the last 25 years," Journal of Natural Products, vol. 70, no. 3, pp. 461-477, 2007.

[9] T. C. Jennerjahn and V. Ittekkot, "Relevance of mangroves for the production and deposition of organic matter along tropical continental margins," Naturwissenschaften, vol. 89, no. 1, pp. 2330, 2002.

[10] B. Yan, K. Hong, and Z. Yu, "Archaeal communities in mangrove soil characterized by $16 \mathrm{~S}$ rRNA gene clones," Journal of Microbiology, vol. 44, no. 5, pp. 566-571, 2006. 
[11] J. Xu, Y. Wang, S.-J. Xie, J. Xiao, and J.-S. Ruan, "Streptomyces xiamenensis sp. nov., isolated from mangrove sediment," International Journal of Systematic and Evolutionary Microbiology, vol. 59, no. 3, pp. 472-476, 2009.

[12] H. Long, W. Xiang, T. Zhuang, and P. Lin, "Microorganism resource of mangrove ecosystems," Chinese Journal of Ecology, vol. 24, no. 6, pp. 696-702, 2005.

[13] L. Han, X. S. Huang, I. Sattler, H. Z. Fu, S. Grabley, and W. H. Lin, "Two new constituents from mangrove Bruguiera gymnorrhiza," Journal of Asian Natural Products Research, vol. 9, no. 3-5, pp. 327-331, 2007.

[14] I. Ara, T. Kudo, A. Matsumoto, Y. Takahashi, and S. Omura, "Nonomuraea maheshkhaliensis sp. nov., a novel actinomycete isolated from mangrove rhizosphere mud," The Journal of General and Applied Microbiology, vol. 53, no. 3, pp. 159-166, 2007.

[15] X. C. Xie, W. L. Mei, Y. X. Zhao, K. Hong, and H. F. Dai, "A new degraded sesquiterpene from marine actinomycete Streptomyces sp. 0616208," Chinese Chemical Letters, vol. 17, no. 11, pp. 1463-1465, 2006.

[16] C. E. Salomon, N. A. Magarvey, and D. H. Sherman, "Merging the potential of microbial genetics with biological and chemical diversity: an even brighter future for marine natural product drug discovery," Natural Product Reports, vol. 21, no. 1, pp. 105121,2004

[17] A. M. Pisano, J. M. Sommer, and M. M. Lopez, "Application of pretreatments for the isolation of bioactive actinomycetes from marine sediments," Applied Microbiology and Biotechnology, vol. 25, no. 3, pp. 285-288, 1986.

[18] Y. Takahashi, A. Matsumoto, A. Seino, Y. Iwai, and S. Omura, "Rare actinomycetes isolated from desert soils," Actinomycetologica, vol. 10, no. 2, pp. 91-97, 1996.

[19] E. B. Shirling and D. Gottlieb, "Methods for characterization of Streptomyces species," International Journal of Systemic Bacteriology, vol. 16, no. 3, pp. 313-340, 1966.

[20] E. Küster and S. T. Williams, "Selection of media for isolation of streptomycetes," Nature, vol. 202, pp. 928-929, 1964.

[21] R. M. Atlas, Handbook of Microbiological Media, CRC Press, Boca Raton, Fla, USA, 1993.

[22] J. F. MacFaddin, Biochemical Tests for Identification of Medical Bacteria, Lippincott Williams \& Wilkins, Baltimore, Md, USA, 3rd edition, 2000.

[23] S. T. Williams and F. L. Davies, "Use of antibiotics for selective isolation and enumeration of actinomycetes in soi," Journal of General Microbiology, vol. 38, no. 2, pp. 251-261, 1965.

[24] K. L. Kelly, Inter-Society Color Council-National Bureau of Standards Color Name Charts Illustrated with Centroid Colors, US Government Printing Office, Washington, DC, USA, 1964.

[25] G. Cerny, "Studies on the aminopeptidase test for the distinction of gram negative from gram positive bacteria," European Journal of Applied Microbiology, vol. 5, no. 2, pp. 113-122, 1978.

[26] P. G. Carrillo, C. Mardaraz, S. I. Pitta-Alvarez, and A. M. Giulietti, "Isolation and selection of biosurfactant-producing bacteria," World Journal of Microbiology and Biotechnology, vol. 12, no. 1, pp. 82-84, 1996.

[27] M. L. Lemos, A. E. Toranzo, and J. L. Barja, "Antibiotic activity of epiphytic bacteria isolated from intertidal seaweeds," Microbial Ecology, vol. 11, no. 2, pp. 149-163, 1985.

[28] D. J. Lane, "16S/23S rRNA sequencing," in Nucleic Acid Techniques in Bacterial Systematics, E. Stackebrandt and M. Goodfellow, Eds., pp. 115-175, Wiley, Chichester, UK, 1991.
[29] A. Ginolhac, C. Jarrin, B. Gillet et al., "Phylogenetic analysis of polyketide synthase I domains from soil metagenomic libraries allows selection of promising clones," Applied and Environmental Microbiology, vol. 70, no. 9, pp. 5522-5527, 2004.

[30] J. H. Crosa and C. T. Walsh, "Genetics and assembly line enzymology of siderophore biosynthesis in bacteria," Microbiology and Molecular Biology Reviews, vol. 66, no. 2, pp. 223-249, 2002.

[31] D. Thakur, A. Yadav, B. K. Gogoi, and T. C. Bora, "Isolation and screening of Streptomyces in soil of protected forest areas from the states of Assam and Tripura, India, for antimicribial metabolites," Journal de Mycologie Medicale, vol. 17, no. 4, pp. 242-249, 2007.

[32] G. D. Garcia, M. F. Romero, B. J. Perez, and D. T Garcia, "Thiodepsipeptide isolated from a marine actinomycete WO9527730," Patent Number US5681813, 1999.

[33] A. Grammer, "Antibiotic sensitivity and assay test," in Microbiological Methods, C. H. Collins and P. N. Lyne, Eds., p. 235, Butterworths, London, UK, 1976.

[34] J. D. Thompson, T. J. Gibson, F. Plewniak, F. Jeanmougin, and D. G. Higgins, "The CLUSTAL X windows interface: flexible strategies for multiple sequence alignment aided by quality analysis tools," Nucleic Acids Research, vol. 25, no. 24, pp. 48764882, 1997.

[35] O. Kim, Y. Cho, K. Lee et al., "Introducing EzTaxon-e: a prokaryotic 16s rRNA gene sequence database with phylotypes that represent uncultured species," International Journal of Systematic and Evolutionary Microbiology, vol. 62, no. 3, pp. 716721, 2012.

[36] N. Saitou and M. Nei, "The neighbor-joining method: a new method for reconstructing phylogenetic trees," Molecular Biology and Evolution, vol. 4, no. 4, pp. 406-425, 1987.

[37] K. Tamura, D. Peterson, N. Peterson, G. Stecher, M. Nei, and S. Kumar, "MEGA5: molecular evolutionary genetics analysis using maximum likelihood, evolutionary distance, and maximum parsimony methods," Molecular Biology and Evolution, vol. 28, no. 10, pp. 2731-2739, 2011.

[38] J. Felsenstein, "Confidence limits on phylogenies: an approach using the bootstrap," Evolution, vol. 39, no. 4, pp. 783-789, 1985.

[39] M. A. Kimura, "A simple method for estimating evolutionary rates of base substitutions through comparative studies of nucleotide sequences," Journal of Molecular Evolution, vol. 16, no. 2, pp. 111-120, 1980.

[40] P. Cashion, M. A. Holder-Franklin, and J. McCully, "A rapid method for the base ratio determination of bacterial DNA," Analytical Biochemistry, vol. 81, no. 2, pp. 461-466, 1977.

[41] J. de Ley, H. Cattoir, and A. Reynaerts, "The quantitative measurement of DNA hybridization from renaturation rates," European Journal of Biochemistry, vol. 12, no. 1, pp. 133-142, 1970.

[42] V. A. R. Huss, H. Festl, and K. H. Schleifer, "Studies on the spectrophotometric determination of DNA hybridization from renaturation rates," Systematic and Applied Microbiology, vol. 4, no. 2, pp. 184-192, 1983.

[43] B. Meena, L. A. Rajan, N. V. Vinithkumar, and R. Kirubagaran, "Novel marine actinobacteria from emerald Andaman \& Nicobar Islands: a prospective source for industrial and pharmaceutical byproducts," BMC Microbiology, vol. 13, no. 1, article 145, 2013.

[44] S. H. Cho, J.-H. Han, H.-Y. Ko, and S. B. Kim, "Streptacidiphilus anmyonensis sp. nov., Streptacidiphilus rugosus sp. nov. and Streptacidiphilus melanogenes sp. nov., acidophilic actinobacteria isolated from Pinus soils," International Journal of Systematic 
and Evolutionary Microbiology, vol. 58, no. 7, pp. 1566-1570, 2008.

[45] Y. Huang, Q. Cui, L. Wang et al., "Streptacidiphilus jiangxiensis sp. nov., a novel actinomycete isolated from acidic rhizosphere soil in China," Antonie van Leeuwenhoek, vol. 86, no. 2, pp. 159165, 2004.

[46] L. Wang, Y. Huang, Z. Liu, M. Goodfellow, and C. Rodríguez, "Streptacidiphilus oryzae sp. nov., an actinomycete isolated from rice-field soil in Thailand," International Journal of Systematic and Evolutionary Microbiology, vol. 56, no. 6, pp. 1257-1261, 2006.

[47] Y. Zhou, W. Wei, X. Wang, and R. Lai, "Proposal of Sinomonas flava gen. nov., sp. nov., and description of Sinomonas atrocyanea comb. nov. to accommodate Arthrobacter atrocyaneus," International Journal of Systematic and Evolutionary Microbiology, vol. 59, no. 2, pp. 259-263, 2009.

[48] Y. Zhou, X. Y. Chen, Y. Zhang, W. Wang, and J. Xu, "Description of Sinomonas soli sp. nov., reclassification of Arthrobacter echigonensis and Arthrobacter albidus (Ding et al. 2009) as Sinomonas echigonensis comb. nov. and Sinomonas albida comb. nov., respectively, and emended description of the genus Sinomonas," International Journal of Systematic and Evolutionary Microbiology, vol. 62, no. 2, part 4, pp. 764-769, 2012.

[49] L. Ding, T. Hirose, and A. Yokota, "Four novel Arthrobacter species isolated from filtration substrate," International Journal of Systematic and Evolutionary Microbiology, vol. 59, no. 4, pp. 856-862, 2009.

[50] M. G. Watve, R. Tickoo, M. M. Jog, and B. D. Bhole, "How many antibiotics are produced by the genus Streptomyces?" Archives of Microbiology, vol. 176, no. 5, pp. 386-390, 2001.

[51] S. D. Bentley, K. F. Chater, A.-M. Cerdeño-Tárraga et al., "Complete genome sequence of the model actinomycete Streptomyces coelicolor A3(2)," Nature, vol. 417, no. 6885, pp. 141-147, 2002.

[52] P. Nimnoi, N. Pongsilp, and S. Lumyong, "Endophytic actinomycetes isolated from Aquilaria crassna Pierre ex Lec and screening of plant growth promoters production," World Journal of Microbiology and Biotechnology, vol. 26, no. 2, pp. 193-203, 2010.

[53] L.-H. Lee, Y.-K. Cheah, S. M. Sidik et al., "Molecular characterization of Antarctic actinobacteria and screening for antimicrobial metabolite production," World Journal of Microbiology and Biotechnology, vol. 28, no. 5, pp. 2125-2137, 2012.

[54] C. H. Cho, J.-S. Lee, D.-S. An, T. W. Whon, and S.-G. Kim, "Nocardioides panacisoli sp. nov., isolated from the soil of a ginseng field," International Journal of Systematic and Evolutionary Microbiology, vol. 60, no. 2, pp. 387-392, 2010.

[55] L. H. Lee, N. Zainal, A. S. Azman, N. S. Mutalib, K. Hong, and K. G. Chan, "Mumia flava gen. nov., an actinobacterium of the family Nocardioidaceae," International Journal of Systematic and Evolutionary Microbiology, vol. 64, no. 5, pp. 1461-1467, 2014.

[56] L. G. Wayne, D. J. Brenner, R. R. Colwell et al., "Report of the Ad Hoc committee on reconciliation of approaches to bacterial systematics," International Journal of Systematic Bacteriology, vol. 37, no. 4, pp. 463-464, 1987.

[57] L. H. Lee, A. S. Azman, N. Zainal et al., "Microbacterium mangrovi sp. nov., an amylolytic actinobacterium isolated from Tanjung Lumpur mangrove forest," International Journal of Systematic and Evolutionary Microbiology, 2014.

[58] E. Stackebrandt and B. M. Goebel, "Taxonomic note: a place for DNA-DNA reassociation and $16 \mathrm{~S}$ rRNA sequence analysis in the present species definition in bacteriology," International
Journal of Systematic Bacteriology, vol. 44, no. 4, pp. 846-849, 1994.

[59] A. T. Bull, J. E. M. Stach, A. C. Ward, and M. Goodfellow, "Marine actinobacteria: perspectives, challenges, future directions," Antonie van Leeuwenhoek, vol. 87, no. 1, pp. 65-79, 2005.

[60] A. T. Bull and J. E. M. Stach, "Marine actinobacteria: new opportunities for natural product search and discovery," Trends in Microbiology, vol. 15, no. 11, pp. 491-499, 2007.

[61] H. Bredholt, E. Fjærvik, G. Johnsen, and S. B. Zotchev, "Actinomycetes from sediments in the Trondheim fjord, Norway: diversity and biological activity," Marine Drugs, vol. 6, no. 1, pp. 12-24, 2008.

[62] L. H. Lee, N. Zainal, A. S. Azman et al., "Streptomyces pluripotens sp. nov., a bacteriocin-producing streptomycete inhibiting methicillin-resistant Staphylococcus aureus," International Journal of Systematic and Evolutionary Microbiology, 2014.

[63] S. Omura, H. Ikeda, J. Ishikawa et al., "Genome sequence of an industrial microorganism Streptomyces avermitilis: deducing the ability of producing secondary metabolites," Proceedings of the National Academy of Sciences of the United States of America, vol. 98, no. 21, pp. 12215-12220, 2001.

[64] M. Nett, H. Ikeda, and B. S. Moore, "Genomic basis for natural product biosynthetic diversity in the actinomycetes," Natural Product Reports, vol. 26, no. 11, pp. 1362-1384, 2009.

[65] P. G. Williams, "Panning for chemical gold: marine bacteria as a source of new therapeutics," Trends in Biotechnology, vol. 27, no. 1, pp. 45-52, 2009.

[66] J. E. Janso and G. T. Carter, "Biosynthetic potential of phylogenetically unique endophytic actinomycetes from tropical plants," Applied and Environmental Microbiology, vol. 76, no. 13, pp. 4377-4386, 2010.

[67] S. Qin, J. Li, H.-H. Chen et al., "Isolation, diversity, and antimicrobial activity of rare actinobacteria from medicinal plants of tropical rain forests in Xishuangbanna China," Applied and Environmental Microbiology, vol. 75, no. 19, pp. 6176-6186, 2009.

[68] R. Finking and M. A. Marahiel, "Biosynthesis of nonribosomal peptides," Annual Review of Microbiology, vol. 58, pp. 453-488, 2004.

[69] S. Courtois, C. M. Cappellano, M. Ball et al., "Recombinant environmental libraries provide access to microbial diversity for drug discovery from natural products," Applied and Environmental Microbiology, vol. 69, no. 1, pp. 49-55, 2003.

[70] A. Hornung, M. Bertazzo, A. Dziarnowski et al., "A genomic screening approach to the structure-guided identification of drug candidates from natural sources," ChemBioChem, vol. 8, no. 7, pp. 757-766, 2007.

[71] M. Metsä-Ketelä, V. Salo, L. Halo et al., "An efficient approach for screening minimal PKS genes from Streptomyces," FEMS Microbiology Letters, vol. 180, no. 1, pp. 1-6, 1999.

[72] I. Schneemann, K. Nagel, I. Kajahn, A. Labes, J. Wiese, and J. F. Imhoff, "Comprehensive investigation of marine actinobacteria associated with the sponge Halichondria panicea," Applied and Environmental Microbiology, vol. 76, no. 11, pp. 3702-3714, 2010.

[73] A. Ayuso-Sacido and O. Genilloud, "New PCR primers for the screening of NRPS and PKS-I systems in actinomycetes: detection and distribution of these biosynthetic gene sequences in major taxonomic groups," Microbial Ecology, vol. 49, no. 1, pp. 10-24, 2005. 

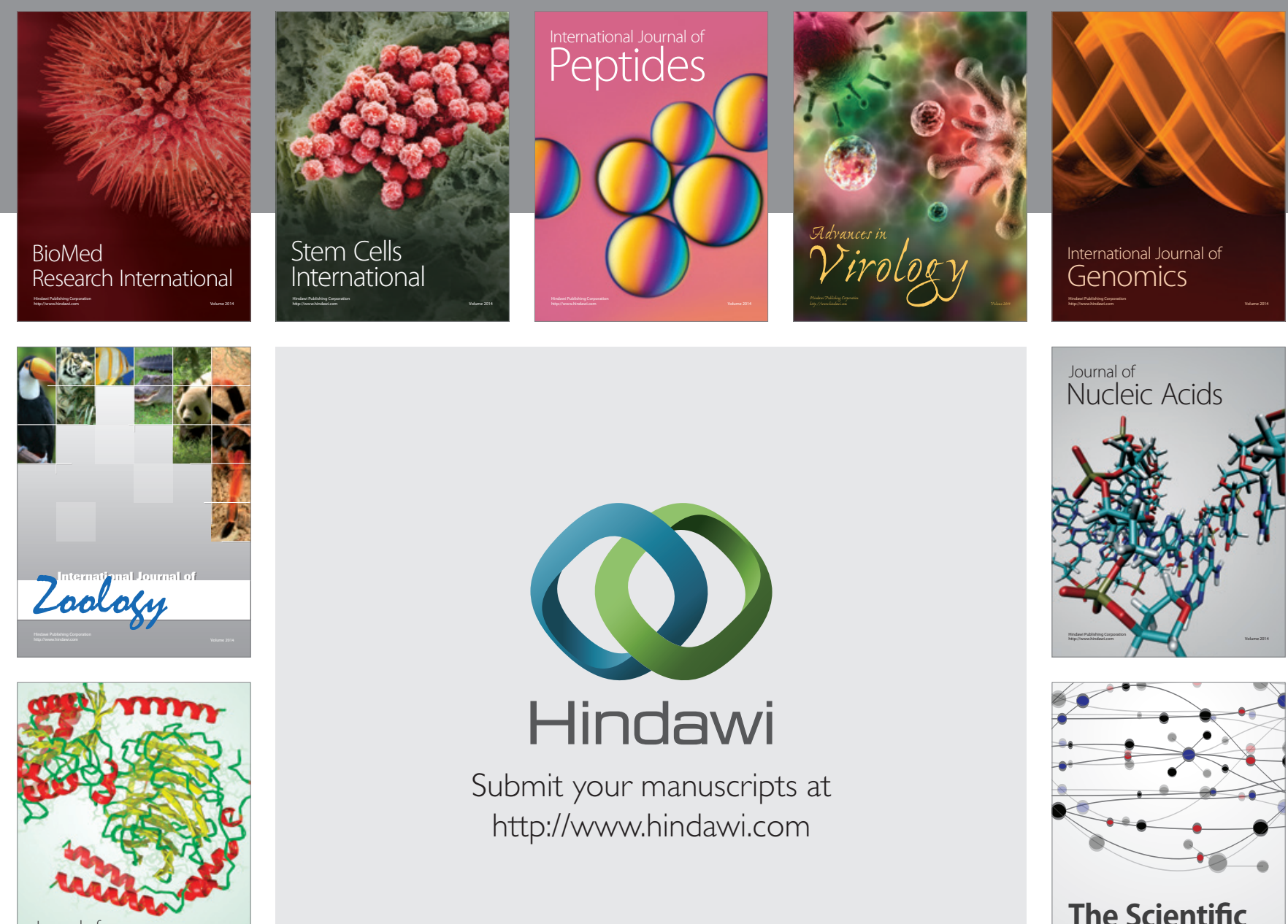

Submit your manuscripts at

http://www.hindawi.com

Journal of
Signal Transduction
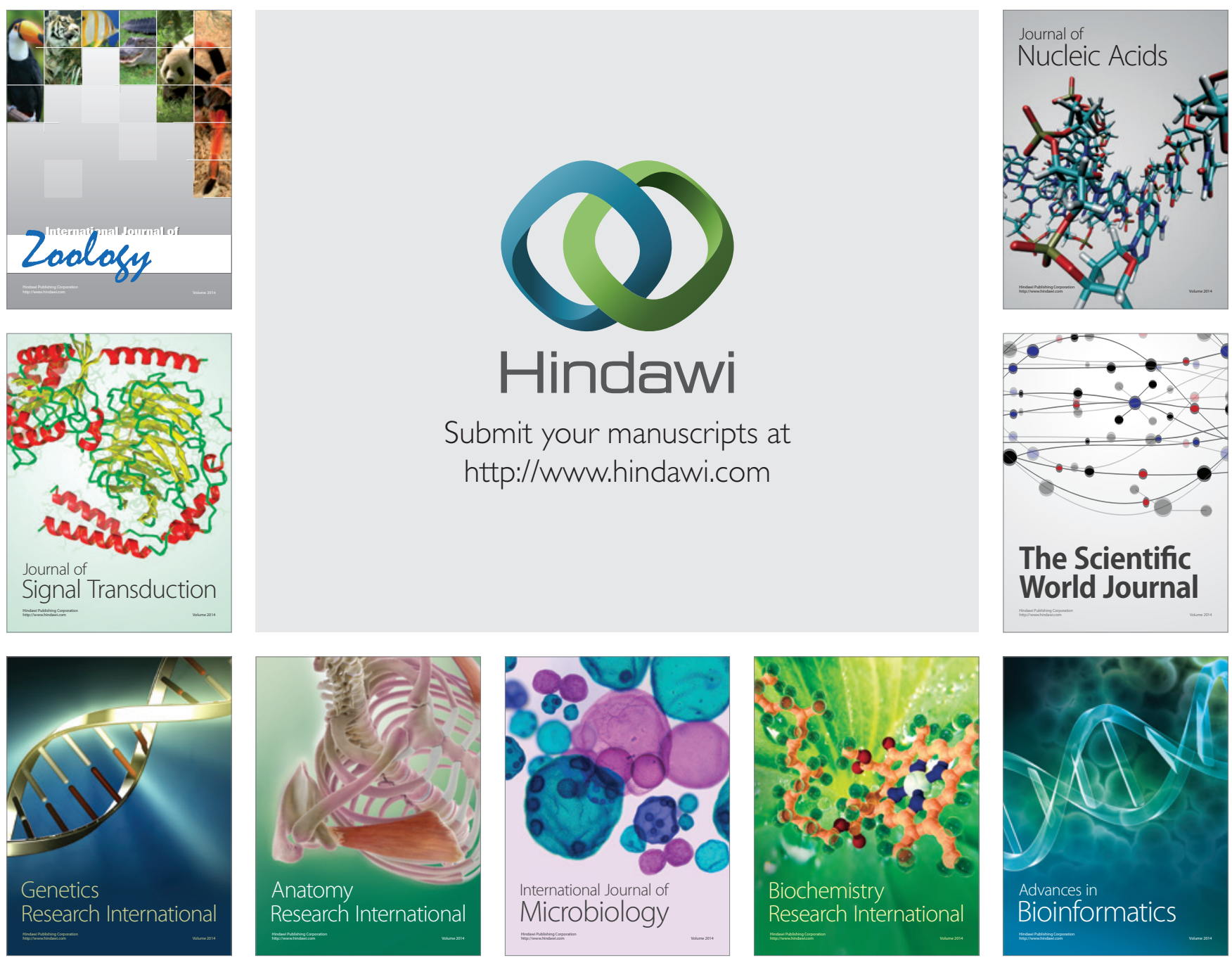

The Scientific World Journal
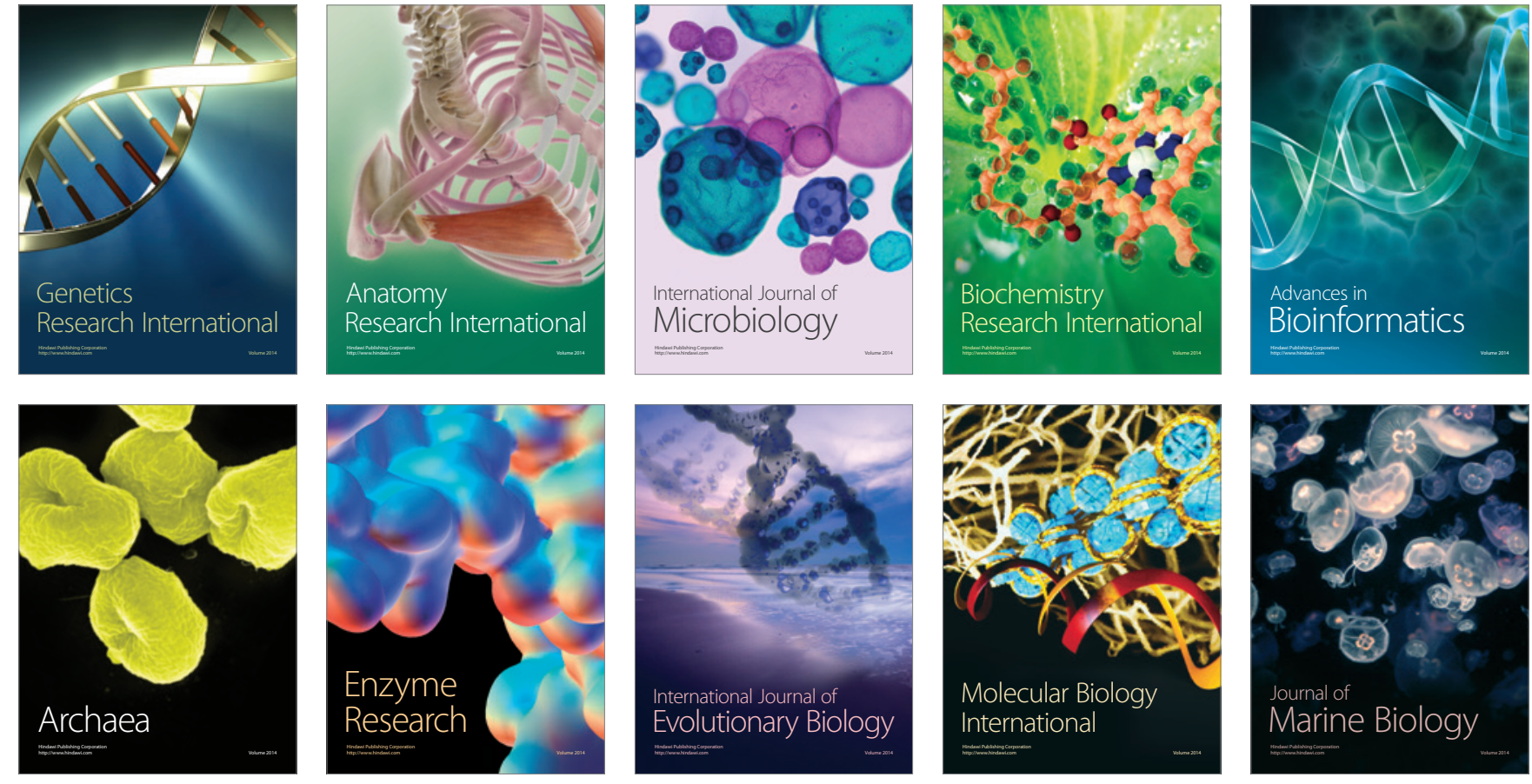